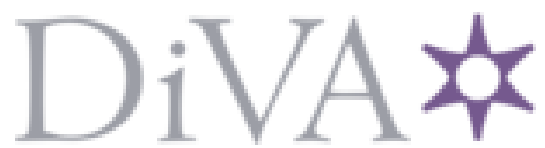

http://www.diva-portal.org

This is the published version of a paper published in European Educational Research Journal (online).

Citation for the original published paper (version of record):

Hansson, P., Öhman, J. (2021)

Museum education and sustainable development: A public pedagogy

European Educational Research Journal (online), :

147490412110564-147490412110564

https://doi.org/10.1177/14749041211056443

Access to the published version may require subscription.

N.B. When citing this work, cite the original published paper.

Permanent link to this version:

http://urn.kb.se/resolve?urn=urn:nbn:se:oru:diva-96193 


\section{Museum education and sustainable development: A public pedagogy}

\author{
Petra Hansson
}

University of Oslo, Norway

\section{Johan Öhman}

Örebro University, Sweden
European Educational Research Journal

(c) The Author(s) 2021

(c) (i)

Article reuse guidelines: sagepub.com/journals-permissions DOI: 10.1 | $77 / 1474904 \mid 2$ II 056443 journals.sagepub.com/home/eer

(SAGE

\begin{abstract}
The question of how sustainability can be incorporated into all areas of society encourages museums to rethink their approaches to society and education. In this article, we argue that museums have the potential to become key public pedagogies for sustainable development and thereby play a crucial role in encouraging participation in sustainability issues. Due to the complexity of sustainability issues, and the potential disturbances of and difficult experiences resulting from exhibitions displaying them, we suggest that a theoretical framing for the teaching and learning of sustainability issues in museums is necessary. Thus, we argue that in relation to exhibitions displaying sustainability issues, museum education would benefit from a didactical framework in which the relation between teaching, learning, content and situation is taken into account. We also argue that a theoretical framework explaining the relation between exhibition, visitor and educational situation could inform pedagogical discussions about how to incorporate sustainability education into museums. Therefore, we suggest a transactional conceptualization of museum pedagogy for sustainability museum education based on John Dewey's educational and aesthetic philosophy and Louise Rosenblatt's theory of reading and writing as a potential approach to the teaching and learning of sustainability issues in museum education.
\end{abstract}

\title{
Keywords
}

Sustainability, museums, museum education, aesthetic experience, transaction, Louise Rosenblatt, aesthetic reading

\section{Introduction}

Museums and museum studies are affected by the fact that the world is facing serious sustainability challenges. Today, contemporary museums are demonstrating an increased interest in exhibiting and discussing complex sustainability issues, such as climate change, migration, 
peace and justice. Since the adoption of the 2030 Agenda for Sustainable Development by all United Nation member states, its 17 sustainable development goals (SDGs) have guided the work to transform the world by ending poverty, protecting the planet and ensuring prosperity for all. The question of how sustainability can be incorporated into all areas of society encourages museums to rethink their approaches to society and education. Incorporating sustainability education into museums' educational programmes is a new opening (McGhie, 2019) and raises questions about what a 'sustainability museum education' might look like and the kinds of pedagogical principles that need to be considered when establishing such a practice. This article contributes to the discussion about museums as public pedagogies for sustainable development. Here, we argue that museums have the potential to become key public pedagogies for sustainable development and thereby play a crucial role in encouraging participation in sustainability issues. The connection between museum education and formal education is a key aspect in discussions about the pedagogical role of museums (Trofanenko and Segall, 2014). In the article we pay particular attention to museum education designed for schools and suggest a transactional pedagogy for sustainability museum education based on John Dewey's educational and aesthetic philosophy and Louise Rosenblatt's theory of reading and writing. We view museums as sites of public pedagogy, which means that museums are regarded as informal yet institutionalized spaces of learning (Sandlin et al., 2010).

In recent years, the connections between museums, sustainable development and education for sustainable development have attracted increased attention in the museum policy discourse. For example, in 2019 the International Council of Museums (ICOM) accepted the recommendation put forward by its working group on sustainability. In the first resolution, the recommendation is that ICOM should recognize that all museums have a role to play in shaping and creating a sustainable future and should 'assist in all ways possible, the goals and targets of the UN SDGs and use the 2030 "Transforming our World" Agenda as the guiding framework to incorporate sustainability into our own internal and external practices and educational programming' (ICOM, 2019). In relation to this, the publication 'Museums and Sustainable Development Goals: A how-to guide for museums, galleries, the cultural sector and their partners' (McGhie, 2019) serves as a first attempt to situate museum education in Agenda 2030. Here it is stated that 'museums can play a crucial role in enhancing public education and participation with the SDGs' (McGhie, 2019: 32). Furthermore, one of the proposed seven key activities to connect museums to the SDGs concerns education (SDG 4) in general and education for sustainable development (ESD) in particular; it is suggested that 'museums can incorporate ESD into all of their educational programmes, for all ages and abilities' (McGhie, 2019: 50). In this sense, sustainability education in museums is both a new topic and a new task for museums and museum education. Accordingly, discussions about the pedagogical role that museums as public institutions could and should play in working towards the SDGs, and how museums could organize exhibitions and educational programmes that promote and empower sustainable development teaching, learning and action, will probably define museum policy and museum education research for some time to come. This gives rise to several pedagogical and theoretical challenges concerning how to incorporate sustainability into museums' educational programmes and exhibitions displaying sustainability issues.

\section{Sustainability issues and the transformative museum}

The task of incorporating sustainability education connected to Agenda 2030 and the SDGs in museums is in its infancy. However, museums are already playing an important role in addressing complex sustainability issues, such as migration, inequality and climate change (McGhie, 2019). In our reading of museum studies, we have identified four themes as relevant starting points for 
discussing a pedagogy for teaching and learning sustainability in museums. The first theme involves paying attention to complex sustainability issues such as climate change, migration and racism - which incidentally are nothing new for museums, even though they are not always named as relating to 'sustainability' (Silvén and Björklund, 2006). For example, Cameron (2010) discusses 'hot topics', Tinning (2017) discusses 'difficult matters', while Tøndborg (2013) looks at 'controversial topics'. According to Rose (2014: 116), such controversial topics or 'hard stuff in museums includes interpretative content about histories of mass violence, slavery, racism, genocide, war, the HIV/Aids epidemic, and other traumatic events'.

The second theme is that museums, with their collections of art, natural and cultural objects, have historically been viewed as pedagogical and, as such, providers of meaningful knowledge and experiences (Hein, 1998). Over the years pedagogical discussions about museum education have focused on different aspects, such as which knowledge and what kinds of experiences are considered important (Ljung, 2009; Tinning, 2017). In general, the museum discourse can be said to be characterized by a discourse of optimism on what museum exhibitions and objects can provide and evoke in terms of knowledge, learning or powerful experiences. In addition, the power of museum exhibitions to engage visitors both personally and emotionally has been discussed for a long time (Illeris, 2006). For example, Latham $(2007,2013)$ argues that through their exhibitions and objects museums offer visitors particularly powerful experiences, which she calls numinous experiences. These discussions highlight the capacity of museums to offer a variety of personal, emotional and affective experiences and is something that we consider to be especially relevant for the teaching and learning of sustainable development.

Thirdly, the introduction of controversial themes and content into museum exhibitions has changed the traditional pedagogical purposes of museums. As Tøndborg (2013) expresses it (p. 6): 'Traditionally, museums were expected to emanate culture and learning, and present a rounded perspective on things. Museums resolved. Museums were not expected to stir things up and act dangerously'. Displaying and discussing 'controversial topics' are often accompanied by an ambition to engage visitors and encourage societal change (Tøndborg, 2013). Such a 'transformative turn' of museums has added a new layer to the pedagogical role of museums by addressing them as 'agents of social change' (McCall and Gray, 2014: 22). Museum exhibitions on difficult matters are often constituted as having the power to contribute to change (Tinning, 2017). Different ways in which transformation can be achieved have been discussed. For example, Witcomb (2015: 322) uses the concept of 'a pedagogy of feeling' to discuss how the staging of affective encounters between visitors and exhibitions can promote introspective reflection and action. She argues that 'difficult historical exhibitions' can 'work poetically to provoke unsettlement in their viewers by playing with their collective memories about the past, challenging them to rethink who they think they are and who they think they are viewing' (Witcomb, 2013: 256).

The fourth and final theme is that the relation between formal education and museum education has changed in recent years, and that what Trofanenko and Segall (2014: 2) call 'the pedagogical ambiguity' of museums 'refers to the rapidly growing interaction between educators and museums and the differing conceptions about the educational role museums serve'. In the light of this 'pedagogical ambiguity', the present-day pedagogical role of museums differs radically from that of their traditional past. Today, most museums have an educational department and offer museumbased learning and educational programmes for schools. Consequently, this 'pedagogical ambiguity' connects museums to critical discussions about education, teaching and learning that previously mainly concerned formal education (Trofanenko and Segall, 2014). Thus, the contemporary educational commitment of museums can be characterized as having a close pedagogical relation to schools. This has created a need for critical discussions about the relation between the pedagogical approaches of museums and formal education, as well as a need for increased pedagogical 
reflections on museum education practice. Moreover, this shift also calls for an increased interest in how learning takes place in museums (Trofanenko, 2014).

Taken together, the above-mentioned themes show that museums constitute a platform from which the theoretical and practical aspects of incorporating sustainability issues in museum education can be discussed. However, as there is currently no agreement about how museums should be involved in creating knowledge about sustainability in general (Trofanenko and Segall, 2014), exactly how sustainability education could be incorporated into museum education practice is a challenge (McGhie, 2019). In the following section, some of the pedagogical challenges for the teaching and learning of sustainability issues in museums are considered and discussed.

\section{Pedagogical challenges}

We know from formal educational practice and research that the teaching of sustainable development is a challenging pedagogical task and that there is therefore reason to assume that these pedagogical challenges are equally relevant for museum education. For example, sustainability issues as educational content challenge traditional ways of teaching and learning (Van Poeck et al., 2019). As sustainability issues involve knowledge uncertainties as well as ethical, political, existential and emotional dimensions, it is difficult to 'learn' sustainability issues in the traditional way of understanding learning as a cognitive endeavour. Thus, the teaching of sustainable development not only centres around providing knowledge about sustainability issues, but also includes new ways of helping students to grapple with the complexities, uncertainties and possible solutions (Van Poeck et al., 2019). Accordingly, if sustainability issues cannot be solved in the usual ways, it will be important to include discussions about how to live with the scientific uncertainties embedded in the issues and to discuss and value the different scientific explanations, arguments and opinions that can help to guide students' actions, that is, by adopting a pluralist approach (Öhman and Östman, 2019) and eliciting personal opinions, emotions and concerns (Hansson, 2019; Ojala, 2019). The fact that museums need to broaden their approaches to include more than knowledge about objects and exhibitions is well established in the museum discourse. For example, Latham (2013:18) states that 'many scholars note that the 'softer' aspects of the museum experienceemotional, sensual, physical, affective - are just as valuable to museum visitors as they are to its ability to provide opportunities for informal or free-choice learning'. The traditional view of 'exhibition as education' and an 'object-based epistemology' in which objects are viewed as 'speaking for themselves' (Bedford, 2014) have a long history in discussions about the educative role of museums. However, there has been an epistemological shift from viewing exhibitions as education to seeing them as aesthetic experiences. Bedford (2014: 16-17) argues that 'an aesthetic approach can capture and inspire the deepest kind of personal meaning making, with its potential for transformation'. Discussions about the potential of museums to provide powerful experiences and affective responses to challenging topics have generally concerned ordinary museum visitors rather than students visiting museums for educational purposes. From a pedagogical point of view, the situation changes when students visit museums and means that it is even more important to critically consider why museums should engage students in museum education with exhibitions that 'may disturb and affect visitors' (Tinning, 2017: 15). Bonnell and Simon (2007) point to the fact that exhibits of 'dark histories' can leave museum visitors with negative feelings anxiety and that such 'difficult exhibitions' can evoke strong cognitive and affective experiences. In addition, psychological research has shown that young people in particular are greatly concerned about present day sustainability issues such as climate change (Ojala, 2019). This raises the didactical question of how to offer students opportunities to encounter exhibitions displaying challenging topics, as well as how to take care of their reactions to such encounters. Therefore, a pedagogical framework 
for discussing the pedagogical challenges and ethical responsibilities in relation to the role of museums to 'act dangerously' is important and something that both Ljung (2009) and Tinning (2017) have identified as missing. In addition, Ljung (2009) and Tinning (2017) maintain that there has been a tendency to only discuss learning, rather than the relation between teaching and learning and the museum's pedagogical situation. In the context of pedagogical challenges relating to the teaching and learning of sustainability issues as discussed above, we consider it important to take teaching, learning and the museum context into account when discussing sustainability museum education. Finally, very few empirical studies of encounters between students and exhibitions that can inform and add perspectives to museum education have been conducted in museum studies (Ljung, 2009). The same is true for empirical investigations into visitors' experiences of encountering 'difficult matter' in exhibitions from a pedagogical point of view (Tinning, 2017).

In sum, based on the reasoning above, we acknowledge that museum exhibitions and museum visits can evoke different kinds of experiences. However, due to the complexity of sustainability issues and the potential disturbances and experiences that exhibitions displaying challenging topics may evoke for students, we suggest that a theoretical framing of the teaching and learning of sustainability issues in museums is needed if museums are to succeed in their ambition to incorporate sustainability education into their practices. Thus, we suggest that in relation to exhibitions displaying sustainability issues, museum education would benefit from a didactical framework in which the relation between teaching, learning, content and situation is considered. Therefore, we argue that a theoretical framework that explains the relation between exhibition, visitor and educational situation could inform pedagogical discussions about how to incorporate sustainability education into museums. In addition, we hope that such a theoretical understanding would inform and encourage further discussions about how to develop museum sustainability education. Issues such as the educational purposes of encountering exhibitions, how encounters with sustainability issues are staged, how students' reactions are taken care of need to be considered. It is important to emphasize that our intention here is to suggest and critically discuss a pedagogy, rather than coming up with a method for how museum education in relation to exhibitions displaying sustainability issues is best organized and carried out. Accordingly, our main ambition is to suggest a theoretical language that can be used to nurture further pedagogical discussions about museums as public pedagogies for sustainable development. The transactional pedagogy suggested below is situated in a didactical framework and especially emphasizes a pedagogical approach to sustainability museum education that encourage dialogues between exhibitions displaying complex sustainability themes as content and the students' own lives.

\section{A transactional pedagogy of museum education on sustainability issues with a particular focus on aesthetic experience}

In the following, the theoretical starting points for the suggested transactional pedagogy are explained. The theoretical approach rests on transactional didactical ground and has been developed through an abductive process between theory, previous museum and education research and new empirical material consisting of students' written responses to an activity included in the educational programme connected to the temporary exhibition A Right to Freedom-Martin Luther King, Jr. at the Nobel Prize Museum in Stockholm, Sweden.

Whether consciously or unconsciously, all pedagogies aim to influence learning and experience (Giroux and Simon, 1988: 12). The suggested transactional pedagogy is set in a Scandinavian and German Didaktik tradition. Most commonly discussed in formal education, Didaktik pays attention to the purpose of education and teaching and learning in relation to the teaching content that students encounter in specific pedagogical contexts. Thus, in the Didaktik 
tradition the teaching and learning situation is regarded as a relation between teacher, student and content (Klafki, 1995). If transferred to museums, the didactical situation of museums can be conceptualized as a relation between the museum educator who is responsible for selecting the relevant exhibition content, organizing activities and staging encounters with exhibitions, the museum students visiting the museum who are there to 'experience' and 'learn', and the selected content of the museum exhibition situated in the pedagogical space of the museum. Thus, the decisions of curators of exhibitions of what to include or exclude, the selections of museum educators of what to put in the foreground or the background and the choice of activities all influence which meanings can be made, which knowledge can be acquired and which experiences are possible during a museum visit.

The suggested transactional pedagogy combines Dewey and Bentley (1949) theory of transaction, Dewey's (1934/2005) theory of aesthetic experience and Rosenblatt's (1985, 1994, 1995, 2005 ) transactional theory of reading and writing. Dewey's educational and aesthetic philosophies have been extensively discussed in museum studies in relation to museum education (Bedford, 2014; Hein, 2004, 2006) and Louise Rosenblatt's work has also been discussed in the museum context (Latham, 2007). We argue that a transactional museum pedagogy can be a fruitful approach to the teaching and learning of sustainability issues in museum education, because a transactional pedagogy: (a) contributes a relational (transactional) understanding of the relation between object, visitor and pedagogical situation, (b) emphasizes aesthetic readings of exhibitions displaying sustainability issues and (c) regards the goal of education to be participation in a democratic society. At the core of transactional pedagogy is what exhibitions and their objects can become in encounters between students and exhibitions in museum education practice, rather than what they are. This means that meaning or learning is not decided by the exhibition or the visitor alone but in the encounter between the exhibition, the visitor and the pedagogical situation.

A transactional understanding of meaning making and learning underpins the suggested transactional pedagogy, which implies that both the person and what is encountered (here museum objects in a museum exhibition) are transformed in the process. Transactional pedagogy draws particularly on Louise Rosenblatt's transactional theory of reading and writing. Even though her theory is developed in relation to the reading of literature, she claims that it is valuable for discussing encounters with all forms of art (Rosenblatt, 1995). Therefore, we consider the transactional theory of reading and writing to be a valuable theoretical starting point for discussing a transactional museum pedagogy concerning museum visitors' encounters with museum exhibitions. Theoretically, Rosenblatt (2005) regards reading as a transactional event between readers and texts. Accordingly, texts never have meaning, a priori somebody reading it, but become meaningful in the encounter between the reader, the text and the situation. Consequently, meaning is neither located in the text nor in the reader but is constituted in transactions between readers and texts. This view was developed as a reaction to previous literary theories and traditions of teaching literature that located meaning either in the text or in the reader. If transferred to the museum, this implies that museum visitors' experiences are considered to emerge in transactions between situational circumstances, such as museum visitors' previous experiences, the displayed objects, the curated museum space and the social and educational situation. Thus, the museum students' learning experiences depend on what is included in the content of the exhibitions, how museum educators choose to stage encounters between exhibitions and museum students and how students are encouraged to 'read' exhibitions. The didactical challenge is to stage encounters with exhibitions that create meaningful experiences for the students in relation to the purpose of the museum visit.

Drawing on Dewey's concept of aesthetic experience, Rosenblatt pays special attention to aesthetic experience and aesthetic reading. According to Dewey (1934/2005: 39-40), experiencing 
something aesthetically is a mode of experience, which is 'a satisfying emotional quality because it possesses internal integration and fulfilment reached through ordered and organized movement'. For Dewey, aesthetic experience (an experience) has special standing and special potential to evoke emotions and contribute new ways of viewing the world and ourselves in it. As such, they are distinct from the stream of ordinary experience. As Shusterman (2000: 25) argues: 'For Dewey, the essence and value of art are not in the mere artifacts we typically regard as art, but in the dynamic and developing experiential activity through which they are created and perceived'. From such a perspective, art and art objects (such as literary texts or objects in a museum exhibition) are not given special standing in themselves, although as Faust (2000: 15) argues: 'Dewey (1934) and Rosenblatt (1994) propose that what counts as literary aesthetic experience - the work of art - is contingent on what particular readers are able to do at a particular place and time'. Rosenblatt (1994) suggests different purposes, or stances, when approaching a text, which she labels 'efferent' and 'aesthetic' reading stances. Taking an efferent stance, the reader 'transacts' with a text to extract information. When taking an aesthetic stance, the reader transacts with a text to evoke a personal experience. When a reader reads a text aesthetically, the text is evoked and becomes a 'literary work of art' (Rosenblatt, 1994). Even though Rosenblatt (2005) describes the reading transaction as a reciprocal relationship between reader and text, meaning making is not considered as solely individual and therefore not solely dependent on an individual transaction between reader and text. She argues that our readings of texts are simultaneously individual and contextual, thus implying that the meaning making of texts is conditioned by readers, texts and the situations in which the reading takes place. Thus, the reading transaction does not only involve personal experiences, but also the present state, present interests and preoccupations of the reader in particular contexts, such as in educational situations. This means that the educational situation and the pedagogical purposes of the reading move the reading in certain directions and affect which meanings are possible to make. In educational contexts, reading has particular aims and occurs in different social and educational settings. For example, the choice of stance is often decided by the teacher. Rosenblatt (1995) argues that the efferent stance has been the dominating stance to the reading of literature in schools with its emphasis on extracting information from texts, rather than the aesthetic stance emphasizing emotional and personal engagement. This is something that she claims prevents readers in educational contexts from experiencing literary works fully, which she means ruins the potential of the reading of literature to have value and meaning for the readers' lives. In turn, efferent stances to reading hinder the educative power of giving students new insights and perspectives that are relevant for them and for their place in society. Thus, she suggests that aesthetic readings are important starting points for further reflection and inquiry. The understanding of 'aesthetic experience' suggested in the transactional pedagogy presented in this article draws on Louise Rosenblatt's concept of aesthetic experience, which are characterized as: (a) an organic immersion of previous and new experiences, (b) a connection to emotions, needs, problems and aspirations of themselves and other human beings and (c) a stimulation of imagination (Connell, 2008: 31). According to Rosenblatt, such aesthetic experiences are not only relevant for the reading of literature but also for learning and education in a more general sense. In the suggested transactional museum pedagogy, the transactional theory of reading and writing of literature is transferred to the space of the museum. Consequently, aesthetic readings become key features, in that we consider all three characteristic traits of aesthetic experience to be important for the teaching and learning of sustainability issues and for encouraging further engagement and public action.

Transferred to practice, we regard aesthetic readings to have the potential to provide opportunities for students to respond to, express their feelings and thoughts and merge previous experiences with new content and thereby connect the exhibition content to themselves. The concept of 'evocation', which Rosenblatt (1994: 69) defines as 'the lived-through process of building up the work 
under the guidance of the text', is central here. An evocation can be seen as a first tentative attempt to make meaning of a text that can later be responded to and further developed. Thus, the suggested transactional pedagogy differs from museum educational models in which museum objects are regarded as speaking for themselves, or where exhibitions alone are expected to evoke certain experiences. Thus, the visitor-object-situation transaction becomes key. In addition, the transactional pedagogy acknowledges that a museum pedagogy that focuses on learning the facts about sustainability issues is not sufficient if museums are to serve as important fora for the teaching and learning of sustainable development. However, taking a transactional starting point does not mean that science and facts are unimportant. Rather, the museum is viewed as a contested site that is open for diverse responses and reactions.

In the light of the above discussion, the suggested transactional museum pedagogy implies that objects and museum exhibitions are not meaningful or valuable in themselves, but that the real value lies in how students engage with them. Taking a transactional understanding of the visitorobject-situation relationship as a starting point for a museum pedagogy implies a view of meaning as being reciprocally constituted in encounters between the reader (visitor), the text (museum object/exhibition) and the pedagogical situation in the museum. Accordingly, encouraging students to take an aesthetic stance and evoke objects while 'reading' exhibitions is considered important for the teaching and learning of sustainability in museum education. This means that the meaning that students make can be seen in the actions that are carried out in the education programme, that is, in their evocations. The design of the exhibit, the content of the exhibition, the activities the students are invited to engage in and the students' previous experiences will all direct the visitors' experiences in certain directions.

One of the motives for Rosenblatt to develop the transactional theory of reading and writing relates to her vision of how the reading of literature can contribute to public engagement and the creation of a more democratic society. This is based on the idea that the reading of literature can encourage us to relate to other human beings and help to expand our imaginations, both of which are necessary for democratic engagement. She argues that if it is read aesthetically, 'literature fosters the kind of imagination needed in a democracy - the ability to participate in the needs and aspirations of other personalities and to envision the effect of our actions on their lives' (Rosenblatt, 1995: 212). Both Dewey and Rosenblatt view aesthetic experience as a prerequisite for learning and for active engagement and participation in society. In addition, they view aesthetic experience as a means towards further inquiry and personal development. The transactional theory of reading and writing emphasizes the importance of creating educational practices that enhance shifts in perspectives, rather than reproducing predetermined ways of thinking. The purpose of the suggested transactional museum pedagogy is to give students opportunities to encounter sustainability issues aesthetically, since such encounters are regarded as important sources of inspiration for further engagement, creativity and public action on sustainability issues. Based on the above, we argue that museums, with their exhibitions, images and installations, can be regarded as potentially rewarding spaces for learning as an aesthetic experience. However, what museum visitors are encouraged to do when participating in museum education programmes is crucial. This implies that we cannot take for granted that aesthetic experiences 'happen' simply because museums design and display exhibitions in engaging ways. Thus, how the encounter between visitor and exhibition is pedagogically staged and how students are encouraged to 'read' exhibitions are central aspects. In the following, we illustrate the transactional pedagogical framework with the aid of some examples of what happened when we introduced aesthetic reading as one of the activities in an educational programme connected to the A Right to Freedom - Martin Luther King, Jr. exhibition at the Nobel Prize Museum in Stockholm, Sweden. 


\section{The Nobel Prize Museum and A Right to Freedom - Martin Luther King, Jr.}

The main focus of the Nobel Prize Museum is the Nobel Prize Laureates and 'the great issues of our time and shows how we can respond to them through science, humanism and cooperation' (https:// nobelprizemuseum.se/en/cultures-of-creativity) - a theme that is displayed in the museum's permanent exhibition entitled Cultures of Creativity. The Nobel Prize Museum also puts on temporary exhibitions, such as A Right to Freedom-Martin Luther King, Jr. that was displayed from September 2018 to 2019. This exhibit was a collaborative project between the Nobel Prize Museum, Nobel Media and the King Estate, with the aim to: 'bring attention to the importance and necessity of basic human rights; promoting Martin Luther King, Jr.'s vision of equality and justice for all through nonviolence, and providing a common forum where people, have the opportunity to learn and share their ideas and experiences with others' (https://nobelprizemuseum.se/en/new-exhibition-about-martinluther-king-jr-opens-this-autumn/). The exhibition displayed Martin Luther King's strategies and visions, as well as important historical events from the Civil Rights Movement, for example through documentary photographs, films, notes, extracts from newspaper articles, collages and digital media. Thus, the exhibition addressed sustainable development goals such as equality, racism, social injustice, peace and war, as well as collaborative action and protest.

For the purpose of this study, we conducted research at the Nobel Prize Museum for 16 months by collecting students' written responses that they produced while participating in the educational programme connected to the exhibition. The educational programme consisted of four activities: 1 . Introduction to Martin Luther King and the exhibition. 2. Guided tour of the exhibition led by the museum educator. 3. An individual aesthetic reading of one selected documentary photograph. 4. Composing and performing an 'I have a dream' speech in small groups. The empirical data used to illustrate the transactional pedagogy in this article derives from activity number three and consists of a collection of students' written responses to the aesthetic readings. The aim of the aesthetic reading activity was to allow the students to spontaneously explore and experience the exhibition. In Rosenblatt's words, the aim of the activity was to encourage the students to take an aesthetic stance and write down their first tentative reactions to the documentary photographs displayed in the exhibition. The students were asked to walk around the exhibition space, select one photograph and write down their immediate and spontaneous emotions and feelings to it. In the following, we have selected a few of the students' evocations to illustrate and discuss the suggested transactional pedagogy. However, we do not intend to engage in a full analysis of all the empirical material. Rather, the aim here is to illustrate the potential of a transactional pedagogy with a particular focus on aesthetic readings.

\section{An illustration}

A brief comment on three general impressions of the students' aesthetic readings is necessary to begin with. First, we identified: (a) many examples of aesthetical experiences including strong reactions and emotions, (b) existential, political and moral/ethical qualities of aesthetic experiences that are here called aesthetic evocations and (c) non-aesthetic experiences that we have called efferent evocations. Second, even though the primary purpose of the exhibition was to highlight the achievements of Martin Luther King's work and the Civil Rights Movement, rather than portraying sustainability issues per se, we can see from the students' responses that the exhibition is primarily constituted as being about racism, inequalities, injustice, violence and oppression. Third, even though the students were encouraged to choose whichever photograph they found interesting in the museum space, the majority chose images that had been discussed during the 
guided tour preceding the aesthetic reading activity. Thus, the educative situation to a large extent influenced which photographs the students selected and, consequently, how they experienced the exhibition. The following evocation initiates the critical discussion of the transactional pedagogy with a particular focus on aesthetic readings.

Inoticed an image of a dark-skinned woman on her way to school being persecuted by adult white people. I feel sad that the world once looked this way. I feel equally grateful that I did not grow up in such a climate. But I also feel grateful for the way we learn from history. That I get to learn from this, everything that has happened, to be able to see how far the world has come today. That we do not repress history but can learn and grow based on our mistakes. Become stronger as a human race. The picture evokes emotions in me. This visit today has also given me a deeper understanding of how sick racism was, the importance of not letting it happen again and the importance of the equal value of all people. And my own role in it today where exclusion and racism exist. ${ }^{1}$

The chosen image that gave rise to this evocation portrayed Elisabeth Eckford on her way to her first day at Central High School, Little Rock, Arkansas, in 1957. She was one of the 'Little Rock Nine', a group of nine Afro-American students who were the first to enter the school following the decision to desegregate all schools. The image portrays her in the midst of a white mob screaming and protesting against allowing Afro-American students to enter the school. In the exhibition, this image was placed next to another portraying a protest against school integration in Montgomery, Alabama, in 1963, which included a sign with the words 'We want a white school'. This can also be said to enforce the message of segregation and resistance towards school integration.

The above response is an example of an aesthetic evocation that is rich in content and encompasses emotions and understanding. Here, sadness over the past, gratitude for not having grown up in such an environment and gratitude for being given the opportunity to learn from history by visiting the museum are expressed. Ethical, political and personal concerns are evoked and there is also a connection between the past and the present, as well as a meta reflection on having had the possibility to 'learn from history'. This visitor-photograph transaction shows the qualities that characterize an aesthetic experience, or in Rosenblatt (1995, xvi) words, 'the poem as an event in the life of the reader, as a doing, a making, a combustion fed by the coming together of a particular personality and a particular text, at a particular time'. We argue that such aesthetic transactions with museum exhibitions can be particularly valuable in relation to the teaching and learning of sustainability issues, because they can reveal their complexity as well as the variety of ways in which they can be responded to.

\section{Existential, political and moral/ethical evocations}

We identified three varieties of evocation - existential, political and moral/ethical - that are relevant in the context of the teaching and learning of sustainability issues in museum education. As mentioned above, the complexity of sustainability issues and the moral, existential and emotional dimensions of the issues make the teaching and learning of sustainability issues challenging. In relation to this, the variety of evocations, through which many different meanings are expressed, can be seen as a positive outcome. Some evocations explicitly express existential dimensions dominated by personal emotional reactions and reflections, as in the following example written in relation to an image of a sit-in demonstration:

I believe it is extreme how human beings can do this towards other people and that no-one dares to protest. Not that I think I had done anything. I'm too much of a coward. It's so brutal to do this to people just because of their skin colour. But I still see something positive with the event/ image. It gives me hope in 
some way that one white and three black people stand up to all the racists together. I don't think this is ok anywhere. I don't like racism, it shouldn't exist, all people are human beings and have the same rights. My stomach hurts when I see how people treat others because of their skin colour. This image shows me so much, since I have been subjected myself, although not to racism.

As we can see, the evocation is driven by a narrator who also self-reflectively relates the image to personal experiences of some kind of oppression. The existential responses are often moral and ethical and express shame or guilt. In the example below, the moral evocation is expanded into a moral/ethical reflection on the differences between the past and the present and the futility of ordinary present-day habits:

When I see the picture and hear the story of the incident, I feel angry and shocked because I cannot imagine that people can be so inhuman. I also feel ashamed of being white because my ancestors were involved in the horrific events of that time. I feel ashamed that I complain and worry about my problems, for example that the internet is slow and that the milk is running out, when there were people who were treated as rubbish due to the colour of their skin.

Other evocations have a more political touch, deal with society and include more discussions about what we need to do to change oppressive structures in present-day society, and what changes need to be made when it comes to inequality and power differences. These evocations are in a way more 'innocent' than the existential and moral/ethical responses, in that the personal and affective dimensions are less prominent, even though the subject is the driving force, as in the following example:

I can't even imagine how horrible it would feel to live in such an oppressive society and constantly be afraid of what might happen. I hadn't managed to live like that and it ought not to happen again. It is how society is structured, some people view themselves as better than others. We need to change this and be on the same level and treat each other as equals. We need to jump down from our high horses.

What, then, do these aesthetic readings and the varieties of evocations mean for museum education in relation to exhibitions displaying sustainability issues? By making aesthetic readings an integral part of sustainability museum education, and if followed up by museum educators, a deeper understanding of the meanings that students make in the museum space can be reached. This can help to both improve the teaching and contribute insights into how to organize a sustainability museum education that involves sustainability issues and the students' personal lives and thoughts. Although it was not possible to include a follow up activity in the context of the educational programme in this study, it would seem that a wide variety of evocations in response to the themes of the exhibition were elicited through the aesthetic readings. This variety indicates that there is great potential for continued work on the themes displayed in the exhibition and the personal meanings that are expressed. However, for a transactional aesthetic museum pedagogy to work fully, aesthetic readings need some sort of follow up activity. These can be done in various ways, for example by sharing responses or giving the students opportunities to ask questions after the aesthetic reading activity. In this case, the students' written responses were collected by us for the purpose of our research. In order to develop the activity further, responses could be collected by the teacher and function as a starting point for further reflection and inquiry back at school. This could also create closer links between museums and schools. If a follow up like this is not included, there is a risk that students will leave the museum with a feeling of sadness, inadequacy and a sense of being exposed to strong content. In our material, we identified a number of evocations expressing sadness and strong emotional experiences that would have been valuable for further discussion and elaboration. This is an important aspect in relation to how schools follow up museum visits. Aesthetic readings are not ends in themselves but 
should be considered as starting points for expanding students' reflections on their initial emotional reactions. We argue that it is particularly important to follow up students' reactions in relation to the teaching and learning of sustainability issues with moral, ethical and emotional dimensions. In this exhibition, with the themes of racism, protest, resistance and oppression, science was not the most prominent theme. For sustainability issues in which science is a more prominent feature, such as climate change, aesthetic readings can help to increase awareness of more human (emotional, ethical, existential, political) dimensions of sustainability. In addition, in relation to the intangible nature of complex sustainability issues, in this case racism, without any ready-made solutions, the students' aesthetic readings and evocations could function as starting points for further inquiry and thereby contribute to an increased understanding of both the issues and the personal experiences of them. It is also important to bear in mind that an aesthetic experience involves emotions and understanding, even though emotions are the 'driving force'. This means that, as in the examples above, there is an explicit dialogue between the content of the image and the reader and that cognitive and affective elements participate in the making meaning.

We also identified evocations that can be said to be the outcomes of efferent readings that do not include any aesthetical qualities. This means they do not link the new experiences evoked by the exhibition to previous personal experiences, personal emotions or actively use imaginative strategies. Accordingly, these efferent evocations are characterized by being descriptive, such as the following response to an image of a tortured slave:

I think the picture shows how the slaves were treated and how they are abused in their daily lives. It is a very old picture that shows what the slaves'backs can look like. The man in the picture is maybe 35-40years of age, so it shows how a slave has been beaten for over 30 years.

This is interesting from a pedagogical point of view and indicates that not all aesthetic readings result in aesthetic experiences. However, we can conclude that the majority of the evocations in this study have aesthetic qualities and that various aspects are related to sustainability issues, such as the existential, political and moral/ethical dimensions of inequalities, racism and oppression. Thus, this says something about the strength of the transactional pedagogy, in that it makes it possible to discern different 'experiences'. Also, from a didactic perspective, bringing the students' evocations to light can enrich discussions about how to organize activities in relation to exhibitions displaying sustainability issues and thereby provide insights into what students experience when visiting museum exhibitions. This makes it possible for museum educators to evaluate and analyse the educational activities, which is especially important in relation to sustainability issues and the strong reactions they may evoke. As the purpose of aesthetic readings is personal, they can function as powerful starting points for further reflection and inquiry. However, one challenge for the museum educator in this study was that the students' previous experiences, the differences in preparing the museum visit and the students' previous experiences of 'aesthetic readings' were unknown to them. This didactic challenge calls for further collaboration with teachers.

\section{Concluding remarks}

Education and learning have spatial dimensions. Traditional divisions of education are seen in conceptualizations such as 'outdoor education', 'museum education' and in concepts like 'informal' and 'formal' education. In such conceptualizations, formal education institutions, such as universities and schools, are often viewed as the base from which students 'pay visits' to other sites, like forests and museums, and then return to. It is often argued that such places for learning have the capacity to promote certain educational experiences and goals. In the context of museum 
education, the advantages are often discussed in terms of how museums can generate powerful aesthetic experiences. When discussing the role of museums for public pedagogy and sustainability issues in this study, we have explored the museum as a public pedagogy from a transactional point of view. Drawing on Dewey's $(1934 / 2005,1949 / 2008)$ transactional theory and his theory of aesthetic experience and Rosenblatt's $(1985,1994,1995,2005)$ transactional reader-response theory, the museum can be conceptualized as a transactional space. This implies that there is no ideal space in which educative experiences can occur. A transactional understanding of museum education allows us to avoid making a priori decisions about where education and learning best take place. This transactional emphasis implies an open, empirically minded attention to the particular learning situations that can occur in encounters between objects, visitors and exhibitions in the space of the museum. Thus, by conceptualizing museum educational practices as transactional spaces, we can increase our understanding of the conditions that frame the museum as a public space in which complex sustainability issues are negotiated, tested and explored.

The responses collected in this study in relation to the exhibition reveal the complexity of sustainability issues as well as the wide variety of ways in which complex issues can be responded to. Thus, the suggested transactional pedagogy allows for a great variety of readings and evocations involving different emotions, thoughts and ideas that are important to elicit in relation to the complexity of sustainability issues. The issue of following up students' reactions to complex and sometimes frightening themes, such as those displayed in the Martin Luther King exhibition, is a challenge for museum education. Previous research confirms that museum professionals express concern about the negative effects that exhibitions dealing with difficult matters may have on visitors (Tinning, 2017). After having analysed the written responses in this study, this is something that we have also reflected on. Images of sustainability issues can be horrible, frightening and cause distress and anxiety, rather than hope and engagement (Ojala, 2012, 2019). For example, one student concluded the aesthetic reading by saying: 'I need to stop writing now before I start crying'. In order to minimize the risk of students leaving the museum with a sense of despair and hopelessness, some sort of follow up is required. Thus, if aesthetic readings are to be included in museum education programmes connected to exhibitions displaying complex sustainability issues, some form of follow up, either in the context of the museum visit or when the students are back at school, is important. Ljung (2009) mentions that teachers follow up museum visits in numerous ways, and similar thoughts are expressed by Tinning (2017). To further develop sustainability museum education on transactional grounds, it will be important to move beyond these initial evocations and take them further into dialogue with others to be refined and critiqued. Even though this would be possible in the context of the museum visit itself, the connection between museums and schools is crucial if museums are to be better equipped to organize sustainability museum education that not only involves a visit but also enables students to expand and explore the complexity of the sustainability issues that are displayed and their personal responses to them.

\section{Acknowledgements}

We would like to express our special thanks of gratitude to the Nobel Prize Museum in Stockholm, Sweden and especially museum educator Pontus Thunblad for your inspiration and cooperation.

\section{Declaration of conflicting interests}

The author(s) declared no potential conflicts of interest with respect to the research, authorship, and/or publication of this article.

\section{Funding}

The author(s) received no financial support for the research, authorship, and/or publication of this article. 


\section{ORCID iD}

Petra Hansson (iD https://orcid.org/0000-0003-3626-4211

\section{Note}

1. All the responses have been translated from Swedish to English by the authors.

\section{References}

Bedford L (2014) The Art of Museum Exhibitions How Story and Imagination Create Aesthetic Experiences. Walnut Creek: Taylor \& Francis Group. Available at: ProQuest Ebook Central (accessed 18 September 2020).

Bonnell J and Simon RI (2007) 'Difficult' exhibitions and intimate encounters. Museum and Society 5: $65-85$.

Cameron F (2010) Risk society, controversial topics and museum interventions: (Re)reading controversy and the museum through a risk optic. In: Cameron F and Kelly L (eds) Hot Topics, Public Culture, Museums. Cambridge: Cambridge Scholars Publishing, pp.53-75.

Connell JM (2008) The emergence of pragmatic philosophy's influence on literary theory: Making meaning with texts from a transactional perspective. Educational Theory 58: 103-122.

Dewey J (1934) Art as experience. New York: Berkeley Publishing.

Dewey J (1934/2005) Art as Experience. New York, NY: Penguin Books.

Dewey J and Bentley A (1949/2008) Knowing and the known. In: Boydston JA (ed.) The Later Works, 1925-1953, vol. 16. Carbondale, IL: Southern Illinois University Press, pp.1949-1952.

Faust M (2000) Reconstructing familiar metaphors: John Dewey and Louise Rosenblatt on literary art as experience. Research in the Teaching of English 35: 9-34.

Giroux HA and Simon RI (1988) Schooling, popular culture, and a pedagogy of possibility. Journal of Education 170(1): 9-26.

Hansson P (2019) Teaching as a matter of staging encounters with literary texts in environmental and sustainability education. In: Van Poeck K, Östman L and Öhman J (eds) Sustainable Development Teaching: Ethical and Political Challenges. Abingdon, Oxon: Routledge, pp.194-203.

Hein GE (1998) Learning in the Museum. London: Taylor \& Francis Group. ProQuest Ebook Central (accessed 18 September 2020).

Hein GE (2004) John Dewey and museum education. Curator The Museum Journal 47: 413-427.

Hein GE (2006) John Dewey's "wholly original philosophy" and its significance for museums. Curator The Museum Journal 49: 181-203.

ICOM (2019) Resolutions adopted by ICOMs 34th general assembly Kyoto, Japan. Resolution no.1 'on sustainability and the adoption of agenda 2030, transforming our world'. Paris: ICOM. Available at: https:// icom.museum/wp-content/uploads/2019/09/Resolutions_2019_EN.pdf (accessed 13 December 2021).

Illeris H (2006) Museums and galleries as performative sites for lifelong learning: Constructions, deconstructions and reconstructions of audience positions in museum and gallery education. Museum and Society 4: 15-26.

Klafki W (1995) Didactic analysis as the core of preparation of instruction (Didaktische Analyse als Kern der Unterrichtsvorbereitung). Journal of Curriculum Studies 27(1): 13-30.

Latham KF (2007) The poetry of the museum: A holistic model of numinous museum experiences. Museum Management and Curatorship 22: 247-263.

Latham KF (2013) Numinous experiences with museum objects. Visitor Studies 16: 3-20.

Ljung B (2009) Museipedagogik och erfarande [Museum Education and Experience]. PhD Thesis, University of Stockholm, Sweden. Available at: http://urn.kb.se/resolve?urn=urn:nbn:se:su:diva-28755 (accessed 13 December 2021).

McCall V and Gray C (2014) Museums and the "new museology": Theory, practice and organisational change. Museum Management and Curatorship 29: 19-35.

McGhie HA (2019) Museums and the sustainable development goals: A how-to guide for museums, galleries, the cultural sector and their partners. Curating Tomorrow. Available at: https://curatingtomorrow236646048. 
wordpress.com/2021/08/22/coming-soon-mainstreaming-the-sustainable-development-goals-a-resultsframework-for-galleries-libraries-archives-and-museums/ (accessed 13 December 2021).

Öhman J and Östman L (2019) Different teaching traditions in environmental and sustainability education. In: Van Poeck K, Östman L and Öhman J (eds) Sustainable Development Teaching: Ethical and Political Challenges. Abingdon and Oxon: Routledge, pp.71-82.

Ojala M (2012) Hope and climate change: The importance of hope for environmental engagement among young people. Environmental Education Research 18(5): 625-642.

Ojala M (2019) Känslor, värden och utbildning för en hållbar framtid: Att främja en kritisk känslokompetens i klimatundervisning [Feelings, values and education for a sustainable future: Fostering a critical emotional competence in climate education]. Acta Didactica Norge 13(2): 1-17.

Rose J (2014) Commemorative Museum Pedagogy. A psychoanalytic Approach to Engaging Visitors in Exhibits with Difficult Knowledge. In: Trofanenko B and Segall A (eds) Beyond Pedagogy: Reconsidering the Public Purpose of Museums. Rotterdam: Brill. ProQuest Ebook Central (accessed 17 September 2020).

Rosenblatt LM (1985) Viewpoints: Transaction versus interaction - A terminological rescue operation. Research in the Teaching of English 19(1): 96-107.

Rosenblatt LM (1994) The Reader, the Text, the Poem: The Transactional Theory of the Literary Work. Carbondale, IL: Southern Illinois University Press.

Rosenblatt LM (1995) Literature as Exploration. New York, NY: Modern Language Association of America. Rosenblatt LM (2005) Making Meaning With Texts: Selected Essays. Portsmouth: Heinemann.

Sandlin JA, Schultz BD and Burdick J (2010) Handbook of Public Pedagogy: Education and Learning Beyond Schooling. New York, NY: Routledge.

Shusterman R (2000) Pragmatist Aesthetics: Living Beauty, Rethinking Art, 2nd edn. Lanham, MD: Rowman \& Littlefield.

Silvén E and Björklund A (2006) Svåra Saker. Ting och berättelser som upprör och berör (with an introduction in English) [Difficult Things. Things and narratives that anger and touch]. Värnamo: Nordiska museets förlag.

Tinning K (2017) The ambivalent potentiality of vulnerability museum pedagogy in exhibitions on difficult matters and its ethical implications. PhD Thesis University of Lund, Sweden.

Trofanenko B and Segall A (2014) Beyond Pedagogy: Reconsidering the Public Purpose of Museums. Rotterdam: Brill. ProQuest Ebook Central (accessed 17 September 2020).

Tøndborg B (2013) The dangerous museum. Participatory practices and controversy in museums today. The Journal Nordic Museology 2: 3-16.

Van Poeck K, Östman L and Öhman J (2019) Sustainable Development Teaching: Ethical and Political Challenges. Abingdon and Oxon: Routledge.

Witcomb A (2013) Understanding the role of affect in producing a critical pedagogy for history museums. Museum Management and Curatorship 28(3): 255-271.

Witcomb A (2015) Toward a pedagogy of feeling: Understanding how museums create a space for crosscultural encounters. In: Witcomb A and Message K (eds) The International Handbooks of Museum Studies: Museum Theory, 1st edn. John Wiley \& Sons, Ltd, pp. 321-344. https://onlinelibrary.wiley. com/doi/10.1002/9781118829059.wbihms116 (accessed 13 December 2021).

\section{Author biographies}

Petra Hansson has a PhD in Education and is Senior Lecturer in Education at Uppsala University, Sweden. Her research explores teaching and learning sustainability in different places with a special interest in aesthetics and ecocriticism within the context of Environmental and Sustainability Education. Her current research focuses particularly on teaching and learning sustainability in museums.

Johan Öhman is Professor of Education in the School of Humanities, Education, and Social Sciences at Örebro University, Sweden. He is one of the founders of the research group SMED (Studies of Meaningmaking in Educational Discourses), and a leader of the research group ESERGO (Environmental and Sustainability Education Research Group Örebro). He is part of the International Advisory Board of the journals Environmental Education Research and Adventure Education and Outdoor Learning. 